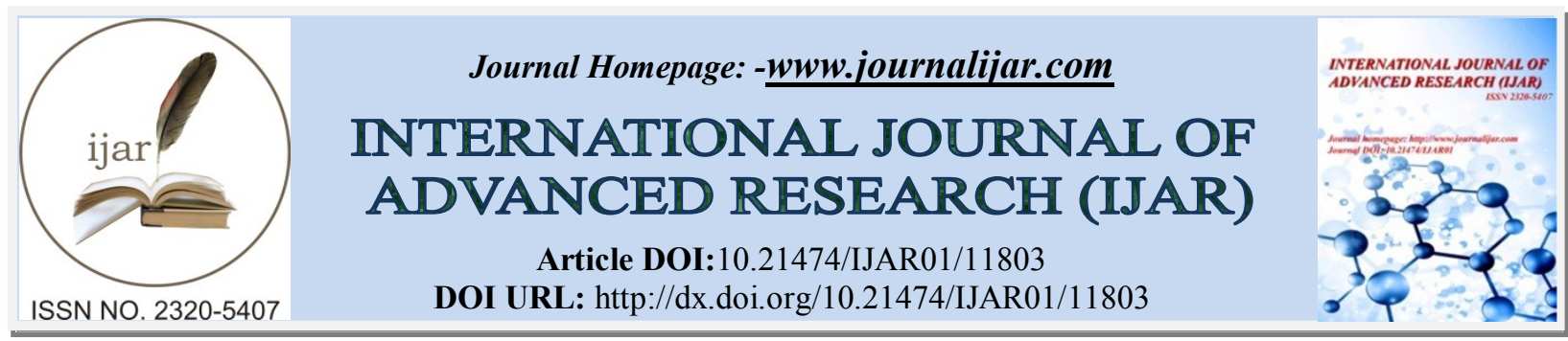

RESEARCH ARTICLE

\title{
CHITINASE PRODUCTION BY ASPERGILLUS TERREUS FROM MARINE WASTES AND ITS EFFICACY IN ANTIFUNGAL ACTIVITY
}

\author{
Shereena E.K., M.K. Nisha and E. Gaayathiri Devi \\ Department of Botany, Avinashilingam Institute for Home Science and Higher Education for Women, Coimbatore- \\ 49, Tamilnadu, India.
}

\section{Manuscript Info}

.........................

Manuscript History

Received: 26 July 2020

Final Accepted: 31 August 2020

Published: September 2020

Key words:-

Antifungal Activity, Aspergillus

Terreus, Chitin, Chitinase, Chitinolytic

\section{Abstract}

The present investigation aims to isolate and identify chitinase producing mycoflora and the chitinase production by efficient Aspergillus terreus on different shell powder wastes substrates such as prawn, crab and molluscs at an extracellular and intracellular level and its efficacy in assessing the antifungal activity. Shell fish wastes disposed soil samples were collected and screened for chitinolytic fungi (hydrolyzing zone). The chitinase production on different substrates was assessed and the enzyme extracts were screened for antifungal activity by agar well and disc diffusion methods. Among the number of mycoflora isolated only 4 fungal strains Aspergillus terreus, A. fumigatus, A. flavus, and A. clavatus showed maximum hydrolyzing zones. A significantly highest hydrolyzing zone (clearance zone) of 20 $\mathrm{mm}$ (out of colony diameter of $65 \mathrm{~mm}$ ) was obtained by Aspergillus terreus. Among the different substrates (prawn, crab and molluscs shell powders at $1 \%$ concentration), highest chitinase activity was recorded by Aspergillus terreus on prawn shell powder waste followed by crab shell powder waste at an intra and extra cellular level. The chitinase produced from prawn shell powder waste as substrates by $A$. terreus showed maximum zone of inhibition in both agar well $(28.0 \mathrm{~mm})$ and disc diffusion $(24.0 \mathrm{~mm})$ methods against the pathogenic fungi, $A$. flavus compared to positive control (Fluconazole). The chitinase produced from $A$. terreus might have synthesized some antifungal compounds which may be responsible for killing pathogenic fungi.

Copy Right, IJAR, 2020,. All rights reserved.

\section{Introduction:-}

Chitin is a polysaccharide, composed of $\beta-1,4 N$-acetyl $\mathrm{D}$ glucosamine residues and is the most abundant renewable resource after cellulose. Chitin chain is present in three forms of arrangement, they are $\alpha, \beta$, and $\gamma$. The $\alpha$ form is dominant and more stable consisting of antiparallel chains. The $\beta$ forms consist of antiparallel chains and occur only in marine organisms. The $\gamma$ chitin is a mixture of both $\alpha$ and $\beta$. The preparation of chitin includes demineralization and deproteinization of shellfish waste material with the use of strong acids and bases $(\mathrm{HCl}$ and $\mathrm{NaOH}$ ). Chitin is mainly derived from crustaceans such as shrimp and crab shells and is mainly composed of calcium carbonate. Is is a structural component of the cell wall of most fungi. Chitin is closely associated with protein, minerals, lipids and pigments. It is insoluble in water but soluble in organic solvents because of its strong intra and intermolecular hydrogen bonds. Some pre-treated chitin is used as a substrate for microbial chitinases 
production. The chitin degrading enzyme, chitinases (EC 3.2.1.14) are a glycosyle hydrolase group of enzymes that catalyse the hydrolysis of insoluble chitin into monomer and oligomer. The microbial extracellular chitinases play an important role in pharmaceutical industry due to their immense potential application like isolation of protoplast of fungi and yeast, preparation of SCP, control of pathogenic fungi, production of bio-pesticides and control of mosquito propagation (Halder et al. 2012). Different types of substrates which contain chitin have been tried for the production of chitinases, which include fungal cell walls, prawn, crab and shrimp shells (Tagawa and Okazaki 1991). Some pre-treated chitin is used as a substrate for microbial chitinases production (Wang and Chang, 1997). Molluscs which are widespread and abundant play an important role in the food chain and are important food sources for larger animals from fish to whales. Shrimp processing industry plays an important role in global economy. The global annual recovery of chitin from the processing of marine crustacean waste is estimated to be around 37,300 metric tons (Sheikh and Deshpande 1993). The shell fish industry is operative among all the costal countries and contribute hugely to to the food delicacies. During the processing of prawns, shrimps and lobsters mostly, the meat is taken, while the shell and head portions are discarded as wastes which results in huge amount of waste generated throughout the world. The main industrial source of chitin is shellfish waste from processing of crab and shrimp. Biological control, or the use of microorganisms or their secretion to prevent plant diseases offers an attractive alternative or supplement for the control of plant diseases without the negative impact of chemical control. Therefore, biological control tactics have become an important approach to facilitate sustainable agriculture (Wang 1999). Chitinases are generally related with the production of antifungal compounds and extracellular hydrolytic enzyme (chitinases and 1, 3- $\beta$ glucanase). Chitinolytic enzymes are efficient in lysing the fungal cell wall. The microorganisms that produce these enzymes are capable of eradicating fungal diseases that are a problem for global agricultural production.

\section{Materials and Methods:- Isolation of Fungal Species}

Prawn, crab and molluscs shell wastes disposed soil samples were collected from the disposal area in Cochin district, Kerala. The samples were serially diluted and plated on Potato Dextrose Agar medium (PDA) and incubated for seven days at $30^{\circ} \mathrm{C}$. After incubation, the plates were observed for fungal growth and were subcultured and maintained on PDA slants at $4^{\circ} \mathrm{C}$. The fungal isolates were identified based on their morphology, mycelia structure and spore formation (Barron 1968; Ellis 1976; Domsche and Gams 1972).

\section{Screening of Soil Fungal Isolates for Chitinolytic Activity}

The identified fungal strains were grown individually for screening for chitinolytic activity on colloidal chitin agar plates (Sherief et al. 1991a). The clearance zone formed around the colonies was determined by adding 0.1 percent congored solution and counter stained with $1 \mathrm{M} \mathrm{NaCl}$ for 15-20 min. A clear zone of chitinase hydrolysis gave an indication of chitinase producing microorganisms. The diameter of the clear zone was measured to provide a quantitative comparison of chitinolytic activity.

\section{Enzyme production}

Erlenmeyer flasks containing 100ml of colloidal chitin liquid medium (Sherief et al. 1991b), was sterilized at 1 atm for 15 minutes. After cooling, one $\mathrm{ml}$ of Streptomycin sulphate $(10,000 \mathrm{ppm})$ was added and incubated for 5, 7,9 and 11 days at $30^{\circ} \mathrm{C}$ under static conditions. The clear filtrate obtained through Whatman No. 40 was used as a source of extracellular enzyme. A quantity of $5.0 \mathrm{~g}$ of the washed mycelia mat was macerated in five ml of sodium phosphate buffer of $\mathrm{pH} 7.0$ in a pre-chilled mortar and pestle with a pinch of acid washed sand. The homogenate was centrifuged and the supernatant served as crude source of intracellular enzyme.

\section{Chitinase assay}

Chitinase activity was determined by the production of $N$-acetyl-D-glucosamine using DNS method. The reaction mixture consisted of $1 \mathrm{ml}$ of $0.2 \mathrm{M}$ sodium phosphate buffer $(\mathrm{pH} 7.0)$ containing 10 percent of colloidal chitin and $1 \mathrm{ml}$ enzyme solution. The mixture was kept in water bath at $50^{\circ} \mathrm{C}$ for $1 \mathrm{hr}$. The reaction was terminated by adding 1 $\mathrm{ml}$ of 1 percent $\mathrm{NaOH}$ and boiled for 5 minutes at $100^{\circ} \mathrm{C}$ and centrifuged for 10 minutes. $1 \mathrm{ml}$ of the supernatant was mixed with $1 \mathrm{ml}$ DNS solution and boiled at $100^{\circ} \mathrm{C}$ for 10 minutes. Finally, the content was cooled and $5 \mathrm{ml}$ of distilled water was added to the mixture. The absorbance was read at $535 \mathrm{~nm}$ and the protein content was determined by the method of Lowry et al. 1951 . 


\section{Effect of different substrates on enzyme production}

The isolated fungal strain was incubated in the production medium containing $0.50 \mathrm{~g}$ of substrates like prawn shell, crab shell and molluscs shell powder. The enzyme activity for each trial was estimated at $5^{\text {th }}, 7^{\text {th }}, 9^{\text {th }}$ and $11^{\text {th }}$ day of incubation in triplicates.

\section{Screening of the extracts for antifungal activity}

Test fungal strains of Aspergillus niger, A. flavus, A. fumigatus kept in the fungal culture bank of Department of Botany, Avinashilingam University, Coimbatore were taken and maintained as subculture in slants. Antifungal studies were carried out by agar well and disc diffusion methods.

\section{Agar well diffusion method (Smania et al. 1995)}

Each fungal suspension of test microorganisms were spread separately over the surface of PDA plates with cotton swap and five wells each of $6 \mathrm{~mm}$ diameters were made on the agar. The wells were filled with $20 \mu 1$ each of enzyme (obtained from different substrates) along with negative control (phosphate buffer) and positive control (fluconazole) at the centre. The plates were incubated at $30^{\circ} \mathrm{C}$ for 76 hours. The zone of inhibition was calculated by measuring the diameter of clear zone formed around the well.

\section{Disc diffusion method (Bauer et al. 1966)}

Plates were prepared by pouring $20 \mathrm{ml}$ of sterile PDA medium into the sterile petriplates and were inoculated with test organisms. Sterile paper disc (Whatman No.1, $3.6 \mathrm{~mm}$ diameters) impregnated with $20 \mu \mathrm{l}$ quantity each enzyme, phosphate buffer (as negative control) and positive control (fluconazole) and were air dried and placed on the PDA plates. The plates were incubated at $30^{\circ} \mathrm{C}$ for 76 hours. The zone of inhibition was calculated by measuring the diameter of clear zone formed around the disc.

\section{Results and Discussion:-}

\section{Isolation and Screening of Chitinase Producing Fungi}

Among the number of mycoflora like Rhizopus stolonifer, Aspergillus fumigatus, A. flavus, A. terreus, A. clavatus, A. nidulans, Penicillium chrysogenum, etc isolated from the prawn, crab and molluscs shell wastes disposal area soil samples, only 4 fungal strains Aspergillus terreus, A. fumigatus, A. flavus, and A. clavatus showed maximum hydrolyzing zones (Table 1). A significantly highest hydrolyzing zone (clearance zone) of $20 \mathrm{~mm}$ (out of colony diameter of $65 \mathrm{~mm}$ ) was obtained by Aspergillus terreus followed by $14 \mathrm{~mm}$ (out of colony diameter of $55 \mathrm{~mm}$ ) by $A$. flavus. Since, A. terreus showed remarkably prominent clear zone of chitinolytic activity, it was selected as a potential candidate for the enzyme study. Sharaf 2005 obtained clearance zone of $32.0 \mathrm{~mm}, 26.0 \mathrm{~mm}$ and $18.0 \mathrm{~mm}$ respectively by Aspergillus flavus, A. foetidus and A. niger. Jenin et al. 2016 reported that the two fungal species belonging to the genus Aspergillus such as A. niger and A. fumigatus were found to be good chtinase producers.

Table 1:- The diameter of colony and hydrolyzing zone.

\begin{tabular}{|l|l|l|l|}
\hline S.No & Fungal strains & $\begin{array}{l}\text { Colony } \\
\text { Diameter } \\
(\mathrm{mm})\end{array}$ & $\begin{array}{l}\text { Hydrolyzing } \\
\text { Zone(mm) }\end{array}$ \\
\hline 1. & Aspergillus terreus & 65.0 & 20.0 \\
\hline 2. & Aspergillus flavus & 55.0 & 14.0 \\
\hline 3. & Aspergillus fumigatus & 30.0 & 10.0 \\
\hline 4. & Aspergillus clavatus & 20.0 & 9.0 \\
\hline
\end{tabular}

Table 2:- Chitinase activity (Umg ${ }^{-1}$ protein) of Aspergillus terreus on Prawn, Crab and Molluscs shell powder as substrate.

\begin{tabular}{|l|l|l|l|l|l|l|l|l|}
\hline Substrate & \multicolumn{2}{|l|}{ Enzyme Activity } & 5th day & 7th day & 9th day & $\mathbf{1 1}^{\text {th }}$ day & SED & $\begin{array}{l}\text { CD } \\
(\mathbf{p}<\mathbf{0 . 0 5})\end{array}$ \\
\hline \multirow{3}{*}{$\begin{array}{l}\text { Prawn } \\
\text { shell }\end{array}$} & Intra & Control & 0.51 & 0.72 & 0.58 & 0.25 & 0.06 & 0.12 \\
\cline { 2 - 9 } & $\begin{array}{l}\text { with } \\
\text { substrate }\end{array}$ & 2.36 & 4.89 & 2.51 & 1.75 & & \\
\hline
\end{tabular}




\begin{tabular}{|c|c|c|c|c|c|c|c|c|}
\hline \multirow[t]{2}{*}{ Powder } & \multirow[t]{2}{*}{ Extra } & Control & 0.42 & 0.81 & 0.54 & 0.27 & \multirow[t]{2}{*}{0.03} & \multirow[t]{2}{*}{0.05} \\
\hline & & $\begin{array}{l}\text { with } \\
\text { substrate }\end{array}$ & 1.17 & 5.29 & 2.77 & 1.36 & & \\
\hline \multirow{4}{*}{$\begin{array}{l}\text { Crab } \\
\text { shell } \\
\text { Powder }\end{array}$} & \multirow[t]{2}{*}{ Intra } & Control & 0.37 & 0.53 & 0.47 & 0.23 & \multirow[t]{2}{*}{0.02} & \multirow[t]{2}{*}{0.03} \\
\hline & & $\begin{array}{l}\text { with } \\
\text { substrate }\end{array}$ & 1.62 & 3.75 & 2.92 & 0.76 & & \\
\hline & \multirow[t]{2}{*}{ Extra } & Control & 0.51 & 0.74 & 0.50 & 0.46 & \multirow[t]{2}{*}{0.03} & \multirow[t]{2}{*}{0.07} \\
\hline & & $\begin{array}{l}\text { with } \\
\text { substrate }\end{array}$ & 1.77 & 4.23 & 3.22 & 0.95 & & \\
\hline \multirow{4}{*}{$\begin{array}{l}\text { Molluses } \\
\text { shell } \\
\text { powder }\end{array}$} & \multirow[t]{2}{*}{ Intra } & Control & 0.47 & 0.77 & 0.43 & 0.38 & \multirow[t]{2}{*}{0.02} & \multirow[t]{2}{*}{0.04} \\
\hline & & $\begin{array}{l}\text { with } \\
\text { substrate }\end{array}$ & 1.34 & 3.49 & 2.09 & 0.92 & & \\
\hline & \multirow{2}{*}{ Extra } & Control & 0.55 & 0.70 & 0.48 & 0.36 & \multirow[t]{2}{*}{0.06} & \multirow[t]{2}{*}{0.13} \\
\hline & & $\begin{array}{l}\text { with } \\
\text { substrate }\end{array}$ & 1.45 & 3.37 & 1.19 & 0.73 & & \\
\hline
\end{tabular}

Values are mean of three triplicates

$\mathrm{Umg}^{-1}=1 \mu$ mol of N-acetyl-D-glucosamine released $\min ^{-1} \mathrm{mg}^{-1}$ Protein.

\section{Assessing Chitinase Production on Different Substrates (Table 2)}

Among the different substrates (prawn, crab and molluscs shell powder wastes), chitinase activity by Aspergillus terreus showed an enhancement from $2.36 \mathrm{Umg}^{-1}$ to $4.89 \mathrm{Umg}^{-1}$ enzyme protein up to $7^{\text {th }}$ day of incubation and it gradually decreased to $1.75 \mathrm{Umg}^{-1}$ enzyme protein in prawn shell powder waste as substrate compared to control with an enhancement from $0.51 \mathrm{Umg}^{-1}$ to $0.72 \mathrm{Umg}^{-1}$ enzyme protein and it declined to $0.25 \mathrm{Umg}^{-1}$ enzyme protein on the $11^{\text {th }}$ day of incubation. The least enhanced activity was observed in molluscs shell powder waste from 1.34 $\mathrm{Umg}^{-1}$ to $3.49 \mathrm{Umg}^{-1}$ enzyme protein and it decreased to $0.92 \mathrm{Umg}^{-1}$ than the control (from $0.47 \mathrm{Umg}^{-1}$ to 0.77 $\mathrm{Umg}^{-1}$ enzyme protein and declined to $0.38 \mathrm{Umg}^{-1}$ enzyme protein) on the $11^{\text {th }}$ day of incubation at an intracellular level. At an extracellular level, the chitinase activity by Aspergillus terreus was increased from $1.17 \mathrm{Umg}^{-1}$ to 5.29 $\mathrm{Umg}^{-1}$ enzyme proteins up to $7^{\text {th }}$ day of incubation and it gradually declined to $1.36 \mathrm{Umg}^{-1}$ enzyme protien on the $11^{\text {th }}$ day of incubation than the control from $0.42 \mathrm{Umg}^{-1}$ to $0.81 \mathrm{Umg}^{-1}$ enzyme proteins in prawn shell powder waste as substrate. The minimal activity observed was in molluscs shell powder waste from1.45 $\mathrm{Umg}^{-1}$ to $3.37 \mathrm{Umg}^{-1}$ enzyme protein up to $7^{\text {th }}$ day of incubation and it decreased to $0.73 \mathrm{Umg}^{-1}$ enzyme protein than the control (from $0.55 \mathrm{Umg}^{-1}$ to $0.70 \mathrm{Umg}^{-1}$ enzyme protein and decreased to $0.38 \mathrm{Umg}^{-1}$ enzyme protein) on the $11^{\text {th }}$ day of incubation. The present result is on par with the report of (Rattanakit et al. 2002) who found that the chitinase production by Aspergillus sp. S1-13 was increased to 58\% - 65\% when, shrimp powder was used as a substrate. (Setthakaillus et al. 2008) obtained highest chitinolytic activity of 3.1 Uml-1 by Aspergillus sp. Similar finding of highest chitinase production of 26.8 Uml-1 by Aspergillus flavus CFR10 was reported by Suresh and Anilkumar, 2012. Similar view was expressed by Krishnaveni and Ragunathan 2014 who reported the maximum chitinase activity in Shrimp wastes $(4.7 \mathrm{U} / \mathrm{min})$, followed by Snail shell $(4.3 \mathrm{U} / \mathrm{min})$, crab shell $(4.2 \mathrm{U} / \mathrm{min})$ and fish scales (3.7 U/min) by Aspergillus terreus CBNRKR KF529976.

\section{Screening of the enzyme extracts for antifungal activity (Table 3) Agar well diffusion method}

It was observed from the results of the agar well diffusion method that among the enzyme produced from different substrates by Aspergillus terreus, highest zone of inhibition of $28.0 \mathrm{~mm}$ was observed against phytopathogenic fungi, Aspergillus flavus from the chitinase produced from the prawn powder waste as a substrate. This was higher than that observed $(26.0 \mathrm{~mm}$ ) in positive control (fluconazole). The minimum zone of inhibition observed was 10.0 $\mathrm{mm}$ in case of chitinase produced by molluscs powder waste against the phytopathogenic fungus A.niger. The moderate inhibition zone was present in A. fumigatus $(22 \mathrm{~mm})$. The present result is accordance with the result of Brurberg et al. 2000 who reported that chitinase showed much stronger inhibitory activity to Fusarium solani (83\%) compared to Aspergillus flavus (63\%). El-Katatny et al. (2005) found that the purified endochitinases of Trichoderma has shown antifungal activity against Sclerotium rolfsii. Similar result was observed by Gunalan et al. 2012a who found that among the four strains of phytopathogenic fungi tested (Aspergillus niger, Alternaria solani, Rhizopus stolonifera and Fusarium solani), highest antifungal activity was observed against Rhizopus stolonifera from the chitinase produced by A. flavus. 
Table 3:- Inhibition zone of chitinase against phytopathogenic fungi by Aspergillus terreus (agar well and disc diffusion method).

\begin{tabular}{|c|c|c|c|c|c|c|}
\hline \multirow[t]{2}{*}{ Method } & \multirow[b]{2}{*}{$\begin{array}{l}\text { Pathogenic } \\
\text { Fungal strains }\end{array}$} & \multicolumn{5}{|c|}{ Zone of inhibition(mm) } \\
\hline & & Prawn & Crab & Molluscs & $\begin{array}{l}\text { Positive } \\
\text { control } \\
\text { (Fluconazole) }\end{array}$ & $\begin{array}{l}\text { Negative } \\
\text { control } \\
\text { (Phosphate } \\
\text { buffer) }\end{array}$ \\
\hline \multirow{3}{*}{$\begin{array}{l}\text { Agar well } \\
\text { diffusion }\end{array}$} & Aspergillus flavus & 28.0 & 24.0 & 18.0 & 26.0 & 8.0 \\
\hline & Aspergillus fumigatus & 22.0 & 15.0 & 14.0 & 24.0 & 10.0 \\
\hline & Aspergillus niger & 17.0 & 13.0 & 10.0 & 24.0 & 7.0 \\
\hline \multirow{3}{*}{$\begin{array}{l}\text { Disc } \\
\text { diffusion }\end{array}$} & Aspergillus flavus & 24.0 & 22.0 & 13.0 & 23.0 & 10.0 \\
\hline & Aspergillus fumigatus & 21.0 & 11.0 & 11.0 & 22.0 & 8.0 \\
\hline & Aspergillus niger & 16.0 & 15.0 & 10.0 & 20.0 & 6.0 \\
\hline
\end{tabular}

\section{Disc Diffusion Method}

After 5 days of incubation, a crescent growth inhibition was observed around the disc containing chitinase produced by Aspergillus terreus on different substrates (prawn shell, crab shell and molluscs shell powders) against the pathogenic fungi like Aspergillus flavus, A. fumigatus and A. niger. The results of the antifungal activity of chitinase against pathogenic fungi by disc diffusion method revealed that among the chitinase produced by Aspergillus terreus from different substrates, maximum zone of inhibition was obtained in prawn shell powder as substrate $(24.0 \mathrm{~mm})$ against the pathogenic fungi, A. flavus compared to positive control $(23.0 \mathrm{~mm})$. The least antifungal activity of $10.0 \mathrm{~mm}$ was recorded in molluscs powder waste against the pathogenic fungus, $A$. niger. The present finding is in accordance with the result of Sandhya et al. 2004 who found that the extracellular chitinase produced by Trichoderma harzianum TUBF781 showed antifungal activity and with Nampoothiri et al. 2004 who reported that chitinase by Aspergillus niger NCIM563 showed antifungal activity against a fungal strains like Rhizopus, Mucor and Aspergillus sp. Similar view was expressed by Gunalan et al. 2012b that the chitinase produced from Aspergillus flavus acted as a biocontrol agent against the phytopathogenic fungi (A. niger, Alternaria solani, Rhizophus stolonifer and Fusarium solani). The present result is on par with the results of Halder 2013 who also reported the chitinase enzyme exhibited high degree of antifungal activity particularly against pathogenic fungi Aspergillus flavus and Fusarium oxysporum by dissolving their cell wall components.

\section{Conclusion:-}

Thus, it can be deduced from the present investigation, that the candidate Aspergillus terreus, a chitinolytic fungus can be effectively harnessed for its maximum production by using cost effective, cheap substrates (shell fish wastes). The chitinase produced from A. terreus might have synthesized some antifungal compounds which may be responsible for killing pathogenic fungi. From the sea food waste, commercially important enzyme chitinase could be produced and it not only solves the environmental problem of disposal of waste in an ecofriendly manner but also promotes the production of value added products of economic benefits at a cheaper rate.

\section{References:-}

1. Barron G.L. 1968. The genera of hypomycetes from soil, the Williams and Wilkins Co.

2. Balttimore, pp: 364 .

3. Bauer A.W., Kirley M.D.K., Sheeis T.C., Truck M. 1966. Antibiotic susceptibility testi by standardized single disc diffusion method. Am. J. Clin. Pathol. 45: 493-496.

4. Brurberg M.B., Synstad B., Klemsdal S.S., Alten D.M.F., Sundheium L., Eijsink V.G.H. 2000. Chitinase from Serratia marcescens. Microbiology. 4:212-218.

5. Domsche K.H., Gams W. 1972. Fungi in agricultural soils. Longman Group Ltd. London. pp. 290.

6. El-Katatny M.H., Somitsch W., Robra K.H., El-Katatny M.S., Gubitz G.M. 2005. Production of chitinase and 1,3- glucanase by Trichoderma harzianum for control of the phytopathogenic fungus Sclerotium rolfsii. Food Technol. Biotechnol. 38: 137- 180.

7. Ellis M.B. 1976. More Domatiaceous hyphomycetes. Common Wealth Mycological Institute. Kew, London. pp.608.

8. Gunalan G., Sadhana D., Ramya P.R. 2012. Production, optimization of chitinase using

9. Aspergillus flavus and its biocontrol of phytopathogenic fungi. J. Pharm. Re.. 5: 3151-3154.

10. Halder S.K., Maity C., Jana A., Das A., Paul T., Das Mohapatra P.K., Pati B.R., Mondal 
11. K.C. 2013. Proficient biodegradation of shrimp shell waste by Aeromonas hydrophila SBK1 for the concomitant production of antifungal chitinase and antioxidant chitosaccharides. Int. Biodeterior. Biodegradation 79: 88-97.

12. Halder S.K., Maity C., Jana A., Pati B.R., Mondal K.C. 2012. Chitinolytic enzymes from the newly isolated Aeromonas hydrophila SBK1:study of the mosquitocidal activity. Bioctrl. 57: 441-449.

13. Jenin G. A., Babu M. M., Murugan M., Murugan T. 2016. Isolation and Identification of Chitinase Producing Native Fungi From Saltpan of Puthalam, Kanyakumari District.Tamil Nadu, India. J Appl Biol Biotechnol. 4: 001-005.

14. Khan M.A., Hamid R., Ahmad M., Abdin M.Z., Javed S. 2010. Optimization of culture media for enhanced chitinase production from a novel strain of Stenotrophomonas maltophilia using response surface methodology. J Microbiol Biotechn. 20: 1597-1602.

15. Krishnaveni B., Ragunathan R. 2014. Chitinase from marine wastes by Aspergillus terreus and its application in degradation studies. Int J Curr Microbiol Appl Sci. 3: 76-82.

16. Lowry O.H., Rosebrough N.J., Farr A.L., Randall R.H. 1951. Protein measurement with

17. Folin phenol reagent. J. Biol. Chem. 193: 265-275.

18. Nampoothiri K.M., Baiju T.V., Sandhya C., Sabu A., Szakacs G., Pandey A. 2004. Process optimization for antifungal chitinase production by Trichoderma harzianum. Process Biochem. 39: 1583-1590.

19. Rattanakit N., Plikomol A., Yano, S., Wakayama M., Tachiki T. 2002. Utilization of shrimpshell fish waste as a substrate for solid -state cultivation of Aspergillus sp. S1-13: Evaluation of a culture based on chitinase formation which is necessary for chitin assimilation. J Biosci Bioeng. 93: 550-556.

20. Setthakaset P., Pichyangkura R., Ajavakam A., Sukwattanasinitt. 2008. Preparation of N- acetyl-Dglucosamine using enzyme from Aspergillus sp. J. Met. Mater. Miner. 18: 53-57.

21. Shaikh S.A., Deshpande M.V. 1993. Chitinolytic enzymes their contribution to basic and

22. applied research. World J Microb Biot. 9: 468-475.

23. Sharaf E. F. 2005. A potent chitinolytic activity of Alternaria alternata isolated from

24. Egyptian black sand Polish. J. Microbiol. 54: 145-151.

25. Sherief A., M.M.M. El-Sawah., Abd El-Naby. 1991. Some properties of chitinase produced

26. by a potent Aspergillus carneus strain. Appl. Microbiol. Biotechnol. 35:228-230.

27. Smania A., Monache F.D., Smania E.F., Gil M.L., Benchetrit L.C., Cruz, F.S. 1995. Antibacterial activity of a substance produced by the fungus Pycnosporous sanguineus (Fr.) Murr. J. Ethnopharmacol. 45: 177-181.

28. Suresh P.V., Anil kumar P.K. 2012. Enhanced degradation of $\alpha$ - chitin materials prepared

29. from shrimp processing by product and production of $\mathrm{N}$ - acetyl -D glucosamine by thermo active chitinases from soil measophilic fungi. Biodegradation. 23: 597-607.

30. Tagawa K., Okazaki K. 1991. Isolation and some cultural conditions of Streptomyces sp. which produce enzymes lysing Aspergillus niger cell wall. J. Biosci. Bioeng. 71: 230-236.

31. Wang S.L., Chang W.T. 1997. Purification and characterization of two bifunctional chitinase/ lysosomes extracellularly produced by Pseudomonas aeruginosa K-187 in shrimp and crab shell powder medium. Appl. Environ. Microbiol.63: 380-386.

32. Wang S.L., Yieh T.C., Shih I.L. 1999. Production of antifungal compounds by Pseudomonas aeruginosa K-187 using shrimp and crab shell as a carbon source. Enzyme Microb. Technol. 25: 142-148. 